\title{
X-RAY STUDIES AND ANTIBACTERIAL ACTIVITY IN COPPER AND COBALT COMPLEXES WITH IMIDAZOLE DERIVATIVE LIGANDS
}

\author{
ANA MARÍA ATRIA ${ }^{1, *}$, PIEDAD CORTÉS-CORTÉS ${ }^{2,3}$, MARÍA TERESA GARLAND ${ }^{3}$, RICARDO BAGGIO $^{4}$, \\ KARINA MORALES ${ }^{1,2}$, MAURICIO SOTO ${ }^{1,2}$ AND GINO CORSINI ${ }^{*}$
}

\author{
${ }^{1}$ Facultad de Ciencias Químicas y Farmacéuticas. Universidad de Chile. Casilla 233, Santiago1. Chile. \\ ${ }^{2}$ Laboratorio de Bacteriología Molecular, Centro de Investigación Biomédica (CIB), Facultad de Medicina, Universidad Diego Portales. Santiago, Chile. \\ ${ }^{3}$ Facultad de Ciencias Fisicas y Matemáticas. Universidad de Chile. Casilla 487-3, Santiago, Chile. \\ ${ }^{4}$ Departamento de Física, Comisión Nacional de Energía Atómica. Buenos Aires, Argentina.
}

(Received: January 28, 2011 - Accepted: June 13, 2011)

\begin{abstract}
The complexes Diaqua-bis(5-nitroimidazole)-copper(II)-dinitrate (1); Tetrakis(4- phenylimidazole)-copper(II)-dinitrate, ethanol solvate (2); Bis(4phenylimidazole)-bis(acetate)-copper(II) (3); Hexakis(4-phenylimidazole)-cobalt(II)-acetate (4) and Bis(2- phenylimidazole)-bis(acetate)-cobalt(II) (5), have been synthesized. Their structures were determined by X-ray analysis.

The antimicrobial activities of these complexes have been screened in vitro against the microorganisms Escherichia coli, Klebsiella pneumoniae, Shigella flexneri, Salmonella typhi, Salmonella enteritidis, Salmonella enterica, Staphylococcus aureus, Listeria monocytogenes. Complexes (1) and (3) showed antimicrobial activity over Gram positive and negative bacteria by a bacteriostatic effect. On the other hand, complexes (4) and (5) showed antibacterial activity with a bacteriolytic effect over Gram positive and negative bacteria.

The cytotoxicity of complexes (3) and (4) was tested in vitro. These complexes presented cytotoxic effect to values near the MIC.
\end{abstract}

Keywords: copper, cobalt crystal structure, antibacterial activities.

\section{INTRODUCTION}

The importance of metal ions in the vital function of living organisms, from mammalians to bacteria, has been widely recognized. They are incorporated into enzymes and cofactors that are required for various life processes. ${ }^{1-3}$

Copper is an essential trace element for many biological processes. It is found in a variety of enzymes, including the copper centers of cytochrome $\mathrm{C}$ oxidase, the $\mathrm{Cu}-\mathrm{Zn}$-containing enzyme superoxide dismutase, and it is the central metal in the oxygen carrying pigment hemocyanin., ${ }^{4,5}$

Cobalt(II) ion is another important component in biological systems, since it is an essential micro nutrient for all living organisms. It is present in vitamin $\mathrm{B}_{12}$, which is involved in the production red of blood cells. ${ }^{6}$

Another reason for the interest in transition metals and their complexes is their potential use as drugs and diagnostic agents to treat a variety of diseases. Many inorganic complexes show antitumor and antibacterial activity. ${ }^{7-12}$

There are numerous copper(II) compounds that present biological activity as antiinflammatory, anticonvulsive, antifungal, antibacterial, and antimicrobial agents. ${ }^{13-18}$

An example is the trans-bis(acetate)bis(imidazole)copper(II) complex, which exhibits the strongest antitumor activity against the mouse melanoma cancer cell line B16. ${ }^{19}$

Cobalt(II) complexes with N6-substituted adenine derivatives have also been suggested as efficient drugs against human malignant melanoma tumour (G361) osteogenic sarcoma (HOS). ${ }^{20}$

In the present report we describe the synthesis and X-ray structural characterization of complexes: $\left[\mathrm{Cu}(5 \text {-nimid })_{2}\left(\mathrm{H}_{2} \mathrm{O}\right)_{2}\right]\left(\mathrm{NO}_{3}\right)_{2}(\mathbf{1}),\left[\mathrm{Cu}(4 \text {-phim })_{4}\right]$ $\left.\left(\mathrm{NO}_{3}\right)_{2} \mathrm{CH}_{3} \mathrm{CH}_{2} \mathrm{OH}(\mathbf{2}),\left[\mathrm{Cu}(4-\text { phim) })_{2} \text { (Acetate) }\right)_{2}\right]$ (3), [Co(4-phim) $]$ (Acetate) (4), and $\left[\mathrm{Co}(2 \text {-phim })_{2}(\text { Acetate })_{2}\right]$ (5), where 5-nimid = 5-nitroimidazole, 4-phim $=4$-phenylimidazole, and 2-phim $=2$-phenylimidazole.

These complexes were also screened for antibacterial activity against Gram positive and negative bacteria, we determined the antibacterial effects and evaluated their cytotoxic effect on human cells.

\section{EXPERIMENTAL}

2.1 Materials and methods

Copper(II) acetate (98\%), cobalt(II) acetate (99.999\%), copper(II) nitrate $(98 \%)$, 4-phenylimidazole (97\%), 2-phenylimidazole $(97 \%)$, and 5-nitroimidazole $(98 \%)$ were purchased from Sigma-Aldrich and used as received.

\subsection{Synthesis}

The complexes $\left[\mathrm{Cu}(5 \text {-nimid })_{2}\left(\mathrm{H}_{2} \mathrm{O}\right)_{2}\right]\left(\mathrm{NO}_{3}\right)_{2}$ (1) and $\left[\mathrm{Cu}(4-\text { phim })_{4}\right]$ $\left(\mathrm{NO}_{3}\right)_{2} \mathrm{CH}_{3} \mathrm{CH}_{2} \mathrm{OH}$ (2) were synthesized by adding a hot ethanol solution of the organic ligand to a hot aqueous solution of $\mathrm{M}\left(\mathrm{NO}_{3}\right)_{2} \cdot 3 \mathrm{H}_{2} \mathrm{O}$ in $1: 2$ and $1: 4$ ratios, respectively. The resulting solutions were refluxed for $2 \mathrm{~h}$.

Single crystals suitable for X-ray analysis were obtained by slow evaporation of the ethanol solution.

Elemental analysis of carbon, hydrogen and nitrogen were obtained with Fison Carlo Erba EA 1108 analyzer.

Anal. Calcd. for (1) C 16.08; H 1.80; N 12.51. Found: C 15.83; H 1.57; $\mathrm{N} 12.37$

Anal. Calcd for (2) C 56.59; H 4.25; N 17.38. Found: C 56.92; H 4.63; N 17.71 .

The complexes $\left[\mathrm{Cu}(4 \text {-phim })_{2}(\text { acetate })_{2}\right]$ (3) and $\left[\mathrm{Co}(2 \text {-phim })_{2}(\text { acetate })_{2}\right]$ (5) were also synthesized by the method described above using $\mathrm{Cu}\left(\mathrm{CH}_{3} \mathrm{COO}\right)_{2} \cdot \mathrm{H}_{2} \mathrm{O}$ and $\mathrm{Co}\left(\mathrm{CH}_{3} \mathrm{COO}\right)_{2} \cdot 4 \mathrm{H}_{2} \mathrm{O}$, respectively.

Anal. Calcd for (3): C 56.42 H 4.31; N 11.98. Found: C 56.73; H 4.76; N 11.75 .

Anal. Calcd for (5): C 56.98.; H 4.35; N12.08. Found: C 56.79; H 4.26; N 11.82 .

The complex $\left[\mathrm{Co}(4-\mathrm{phim})_{6}\right]$ (acetate) ${ }_{2}$ (4) was prepared by addition of a solution of the ligand $(6 \mathrm{mmol})$ to a solution of $\mathrm{Co}\left(\mathrm{CH}_{3} \mathrm{COO}\right)_{2} \cdot 4 \mathrm{H}_{2} \mathrm{O}(1 \mathrm{mmol})$, both in ethanol.

Anal. Calcd for (4): for C 67.19; H4.67; N 16.21. Found: C 67.57; H 4.85; N 16.65 .

\subsection{Crystal structure determination}

The diffractometer data set was collected up to a $2 \theta$ max of ca. $58^{\circ}$ using monochromatic Mo $\mathrm{K} \alpha$ radiation, $\lambda=0.7107 \AA, \mathrm{T}=295 \mathrm{~K}$ on a Bruker Smart diffractometer driven by the SMART-NT software..$^{21}$ Data reduction and absorption corrections were made using SAINT-NT. ${ }^{22}$ The structure resolution was achieved routinely by direct methods and difference Fourier. The model was refined by least squares on $\mathrm{F}^{2}$, with anisotropic displacement parameters for non- $\mathrm{H}$ atoms. All the hydrogen atoms in the structure (C-H's) were unambiguously defined by the stereochemistry and were accordingly placed in their calculated positions and allowed to ride onto their host carbons both in coordinates as well as in thermal parameters.

Data collection calculations to solve and refine the structures and to obtain derived results were carried out with the computer programs SHELXS97/ SHELXL97, ${ }^{23}$ SHELXTL/PC. ${ }^{24}$ Full use of the CCDC package was also made 
for searching in the CSD Database. ${ }^{25}$ The crystal and refinement details for compounds (1)-(5) are listed in Table 1.

Table 1. Crystal data and structure refinement for complexes (1), (2), (3), (4) and ( 5).

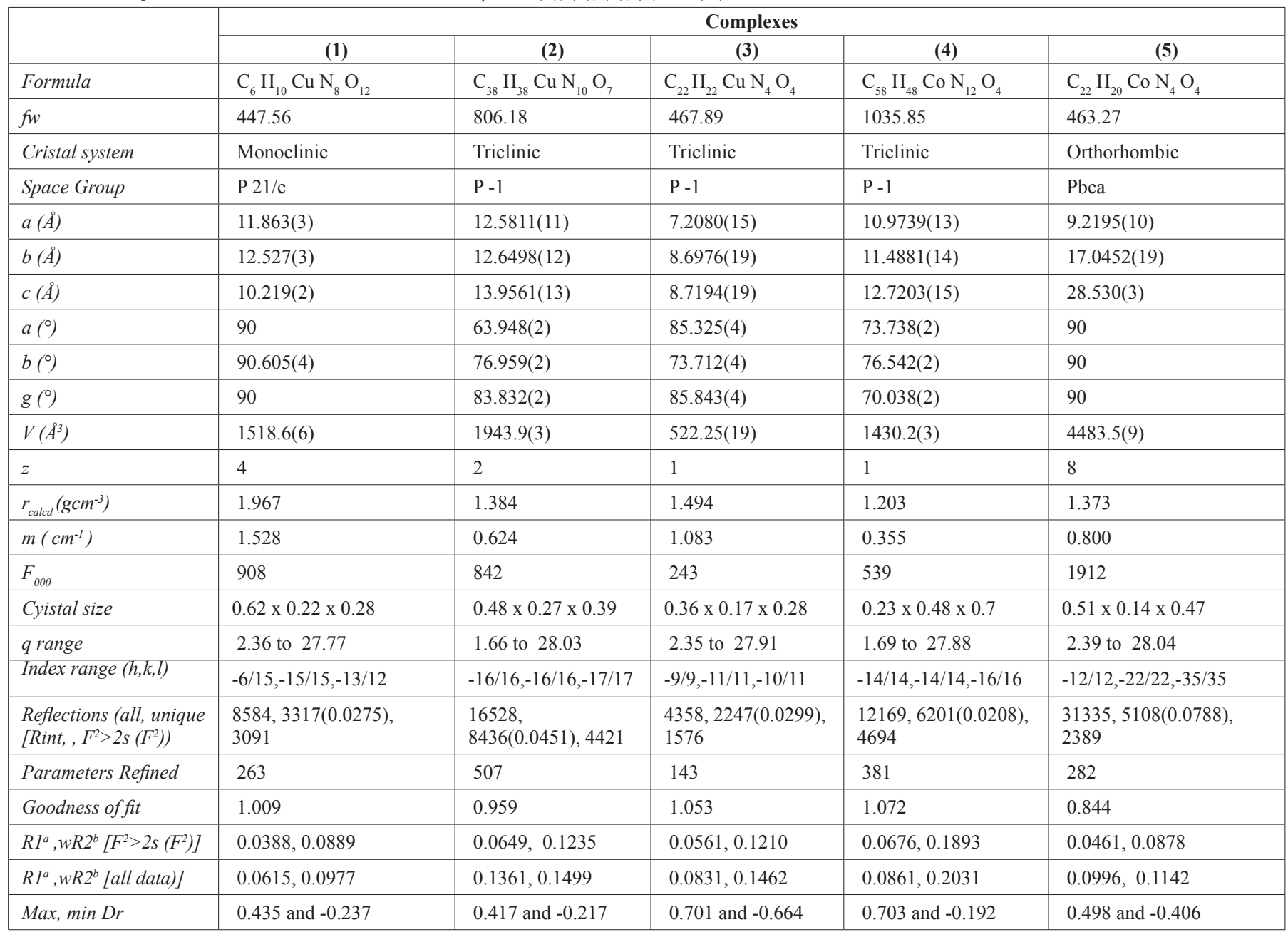

${ }^{a} R 1: S^{1 / 2} 1 / 2 F O^{1 / 2}-1 / 2 F c^{1 / 2} 1 / 2 / S^{1 / 2} F O^{1 / 2} ; \quad{ }^{b} w R 2:\left[S\left[w\left(F O^{2}-F c^{2}\right)^{2}\right] / S\left[w\left(F O^{2}\right)^{2}\right]\right]^{1 / 2}$

2.4 Antimicrobial activity measurement.

Bacterial strains used in this study are the property of the Molecular Bacteriology Laboratory collection (Universidad Diego Portales). Staphylococcus aureus AB68, Shigella flexneri UCH15, Klebsiella pneumoniae RYC492, Escherichia coli O157:H7, and Salmonella enterica UDP1313 strains were isolated from clinical samples, while the Listeria monocytogenes ATCC1513 strain was obtained from American Type Culture Collection. Salmonella enteritidis ISP/953 and Salmonella typhi ISP2714 strains were obtained from Instituto de Salud Pública de Chile (ISP). Escherichia coli DH5a strain was obtained from Gibco BRL and Escherichia coli BL21 strain was obtained from Novagen Inc.

Bacteria were grown in Mueller Hinton agar (Difco) as Mueller Hinton broth (Difco) for 16 to $24 \mathrm{~h}$ at $37^{\circ} \mathrm{C}$ in an incubator.

The in vitro antibacterial activity of the complexes was tested using the paper disc diffusion method, ${ }^{26}$ and quantitative antibacterial activity was determined using minimum inhibitory concentration method (MIC). ${ }^{27}$

\subsection{Antibacterial effect.}

The in vitro antibacterial effect of the complexes was tested using a chromogenic plate test assay. ${ }^{28}$ E. coli BL21(DE3), which contains a chromosomal IPTG-inducible $\beta$-galactosidase gene, was used for the assays. The chromogenic agar plates were prepared as follows. First, an inoculum with this strain was grown overnight in $2 \mathrm{~mL}$ of Mueller Hinton media, at $37{ }^{\circ} \mathrm{C}$ with shaking. Then, a top agar-incubation mix containing $5 \mathrm{~mL}$ of $0.8 \%$ agar previously melted at $45{ }^{\circ} \mathrm{C}$ containing $0.1 \mathrm{~mL}$ of the bacterial cell inoculum, $0.01 \mathrm{~mL}$ of $1 \mathrm{mM} \mathrm{IPTG}$, and $0.1 \mathrm{~mL}$ of $50 \mathrm{mg} / \mathrm{mL} \mathrm{X-Gal} \mathrm{was} \mathrm{vortex-mixed}$ and carefully overlaid on Mueller Hinton agar plates prepared the day before. The discs containing the appropriate concentration of complex or antibiotic were deposited on the chromogenic agar plates. The plates were then incubated at $37^{\circ} \mathrm{C}$ for $12-24 \mathrm{~h}$, the inhibition zones were visually inspected for color formation along de edges of the discs, and the plates were photographed. Only compounds causing cellular lysis produce a blue-colored edge at the inhibition zone.

2.6 Cytotoxic effect

The cytotoxicity of the complexes was tested in vitro on human cells using microplate cultures of human kidney embryonic cells (HEK293 cells) grown in DMEM medium plus $10 \%$ bovine fetal serum. The number of dead cells was determined by an MTT cell proliferation assay after $24 \mathrm{~h}$ of incubation with the complex. ${ }^{29}$ This method is a colorimetric assay system which measures the reduction of a tetrazolium component (MTT) to an insoluble formazan product by the mitochondria of viable cells. The amount of color produced is directly proportional to the number of viable cells. 


\section{RESULTS AND DISCUSSION}

3.1 Description of the structures.

The five structures reported here present a common, distinctive feature in that all of them are monomeric, and the ligands involved behave in a monodentate fashion. On the other hand, they fall naturally into two well defined groups when the cations are considered.

Copper complexes (1), (2) and (3) present coordination arrangements with a well-defined set of four nearest neighbour interactions $(\mathrm{Cu}-\mathrm{O} / \mathrm{N}<2.000(1)$ $\AA ̊$ ), defining a tight square planar geometry. Second nearest neighbours are at much larger, semicoordination distances, viz., $\mathrm{Cu}$... $/ \mathrm{N}>\mathrm{x}, \mathrm{x}=2.459(2) \AA ̊$ in (1), 2.652(3), 2.806(3) $\AA$ in (2), 2.744(3) $\AA$ in (3) which, if taken into account, lead to a variety of polyhedra that will be discussed below.

The cobalt structures, instead, present neat environments, octahedral in (4) and tetrahedral in (5).

a) Copper complexes:

In compound (1) there are two independent, almost identical molecules in the structure (Fig. 1A, 1B), with their copper cations $\mathrm{Cu} 1$ and $\mathrm{Cu} 2$ lying on two different symmetry centers. The square array around each cation is defined by two N-bound 5-nimid groups and two water molecules, and it is perfectly planar due to the imposed symmetry (Table 2). Also planar are the 5-nimid ligands, which present only a slight rotation of the nitro groups (ca. $2.0^{\circ}$ ) around the $\mathrm{C}-\mathrm{N}$ bond. These groups bind almost perpendicular to the $\mathrm{CuN}_{2} \mathrm{O}_{2}$ coordination plane so as to have one of the nitrate oxygens pointing towards $\mathrm{Cu} 1$, at a semicoordination distance and subtending an angle of $17.8^{\circ}(\mathrm{Cu} 1)$ $117.5^{\circ}(\mathrm{Cu} 2)$ to the normal plane, thus fulfilling some kind of an apical role and allowing to the coordination polyhedra to be described as highly distorted octahedra.

Charge balance is achieved by two nitrate counterions located at general position, thus balancing the two copper(II) cations in special position.

A

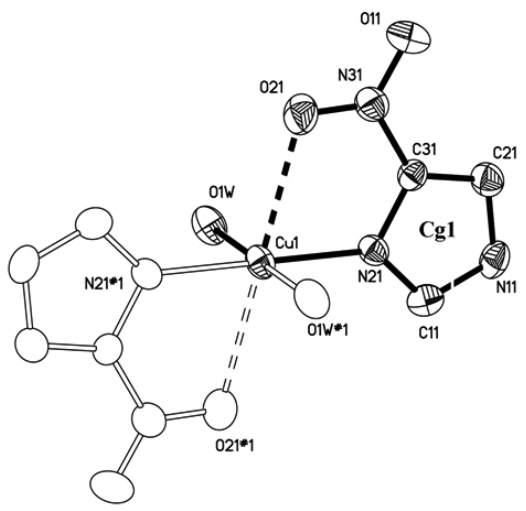

B

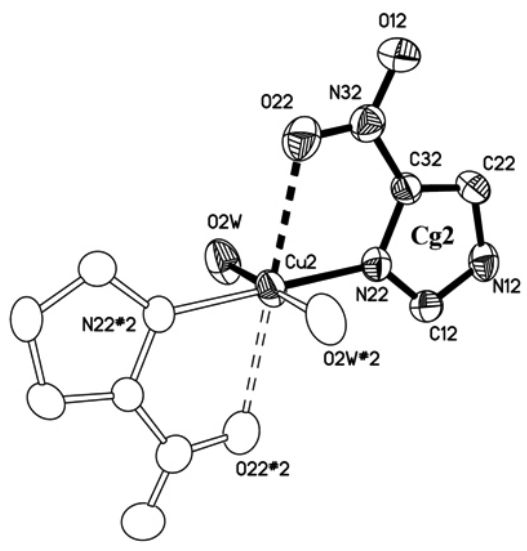

Fig.1. Molecular view of the monomeric units in (1), showing the labelling scheme. In dashed line the semi-coordination of carboxylato oxygen fulfilling the apical role. Displacement ellipsoids drawn at a $30 \%$ level. Symmetry codes \#1, 1-x, 1-y, -z \#2,-x, 2-y, 2-z
In complex (2) the copper cation is coordinated at a general position by four nitrogens from four independent 4-phim ligands, in a neat square planar arrangement (Fig. 2, Table 2). Although cis- coordination angles depart by less than $0.4^{\circ}$ from $90^{\circ}$, the trans- angles differ significantly more (ca. $6.5^{\circ}$ ) from the ideal $180^{\circ}$, thus revealing some departure from planarity. These bond distances and angles of the core are in good agreement with those of the bis(acetate)tetrakis(imidazole)copper(II) complex..$^{30}$

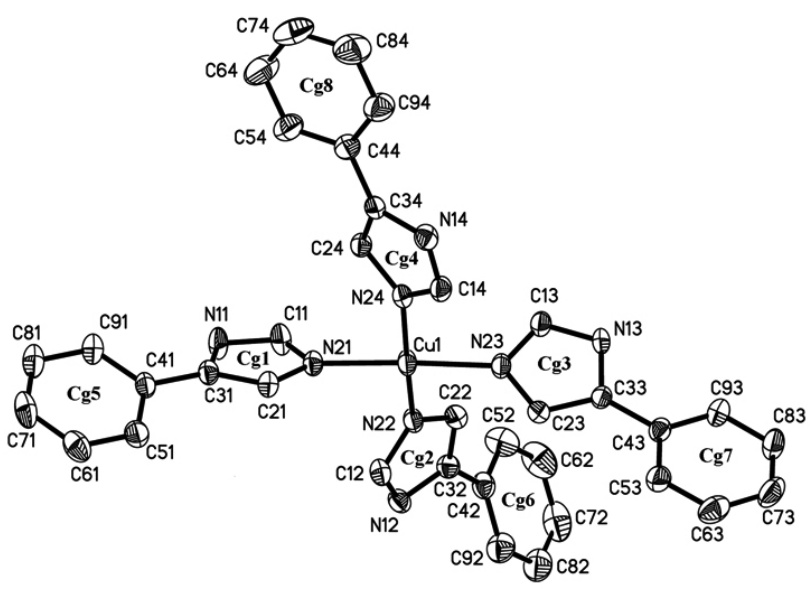

Fig. 2. Molecular view of the monomeric units in (2), showing the labeling scheme. Displacement ellipsoids drawn at a $30 \%$ level.

Two nitrate ions compensate the copper (II) charge (all of them in general positions), in a structure further stabilized by an ethanol solvate. Two oxygen atoms, one from the ethanol molecule and other from one of the nitrate anions, are located on both sides of the cation at weakly interacting distances (2.652(3) $\AA, 2.806(3) \AA$ ) in a highly distorted octahedral arrangement. (5)

Table 2. Selected bond lengths $[\AA]$ and angles $\left[{ }^{\circ}\right]$ for (1), (2), (3), (4) and

\begin{tabular}{|c|c|c|c|}
\hline \multicolumn{4}{|l|}{ Complex (1) } \\
\hline \begin{tabular}{l|l} 
& $\mathrm{Cu} 1-\mathrm{N} 21$ \\
\end{tabular} & $1.971(2)$ & $\mathrm{Cu} 2-\mathrm{N} 22$ & $1.964(2)$ \\
\hline Cu1-O1W & $1.995(2)$ & $\mathrm{Cu} 2-\mathrm{O} 2 \mathrm{~W}$ & $1.992(2)$ \\
\hline $\mathrm{Cu} 1-\mathrm{O} 21$ & $2.459(2)$ & $\mathrm{Cu} 2-\mathrm{O} 22$ & $2.487(2)$ \\
\hline N21-Cu1-O1W & $91.10(8)$ & $\mathrm{N} 22-\mathrm{Cu} 2-\mathrm{O} 2 \mathrm{~W}$ & $89.24(9)$ \\
\hline \multicolumn{4}{|l|}{ Complex (2) } \\
\hline \begin{tabular}{l|l}
$\mathrm{Cu} 1-\mathrm{N} 21$ \\
\end{tabular} & $1.977(3)$ & $\mathrm{Cu} 1-\mathrm{N} 24$ & $2.001(3)$ \\
\hline Cu1-N23 & $1.980(3)$ & Cu1-N22 & $2.001(3)$ \\
\hline N21-Cu1-N23 & 176.81(14) & N21-Cu1-N22 & $90.35(11)$ \\
\hline N21-Cu1-N24 & $90.29(11)$ & N23-Cu1-N22 & $89.67(11)$ \\
\hline \begin{tabular}{l|l} 
N23-Cu1-N24 \\
\end{tabular} & $90.05(11)$ & N24-Cu1-N22 & $173.53(13)$ \\
\hline \multicolumn{4}{|l|}{ Complex (3) } \\
\hline \begin{tabular}{l|l|}
$\mathrm{Cu} 1-\mathrm{N} 21$ \\
\end{tabular} & $1.966(3)$ & $\mathrm{Cu} 1-\mathrm{O} 14$ & $1.975(2)$ \\
\hline N21-Cu1-O14 & $90.05(11)$ & & \\
\hline \multicolumn{4}{|l|}{ Complex (4) } \\
\hline \begin{tabular}{l|l} 
& Co1-N21 \\
\end{tabular} & $2.140(2)$ & Co1-N22 & $2.197(2)$ \\
\hline Co1-N23 & $2.167(2)$ & & \\
\hline N21-Co1-N23 & $92.06(8)$ & N23-Co1-N22 & $89.50(8)$ \\
\hline \begin{tabular}{l|l} 
N21-Co1-N22 \\
\end{tabular} & $91.15(8)$ & & \\
\hline \multicolumn{4}{|l|}{ Complex (5) } \\
\hline \begin{tabular}{|l|l|}
$\mathrm{Co} 1-\mathrm{O} 23$ \\
\end{tabular} & $1.937(2)$ & Co1-N12 & $2.001(2)$ \\
\hline Co1-O14 & $1.964(2)$ & Co1-N11 & $2.031(2)$ \\
\hline O23-Co1-O14 & $107.17(9)$ & O23-Co1-N11 & $99.92(9)$ \\
\hline O23-Co1-N12 & $118.55(9)$ & O14-Co1-N11 & $100.82(9)$ \\
\hline O14-Co1-N12 & $117.12(10)$ & N12-Co1-N11 & $110.49(9)$ \\
\hline
\end{tabular}


In complex (3) the copper cation at a symmetry centre in P-1 is surrounded by two symmetry-related N-coordinated 4-phim ligands and two (also symmetry related) acetato ligands binding only through one of the carboxylato oxygens (Fig. 3). The resulting geometry is an almost perfectly square, strictly planar configuration with the acetate group almost orthogonal to the coordination plane $\left(85.7^{\circ}\right)$. This disposition puts the noncoordinated carboxylato oxygen at 2.744(3) $\AA$ from the cation and at a rather large angle from the vertical (ca. $34^{\circ}$ ) to be considered a real apical interaction. This geometry is comparable with that of the $\mathrm{Cu}\left[\mathrm{CH}_{2}=\mathrm{C}\left(\mathrm{CH}_{3}\right)-\mathrm{COO}\right]_{2}(\mathrm{Him})_{2}$ complex, ${ }^{31}$ which has an environment that is a trans square planar configuration where the homologous noncoordinated carboxylato oxygen is at a distance of $2.45 \AA$ from the cation and the angle from the vertical is too large $\left(\mathrm{ca} 28^{\circ}\right)$.

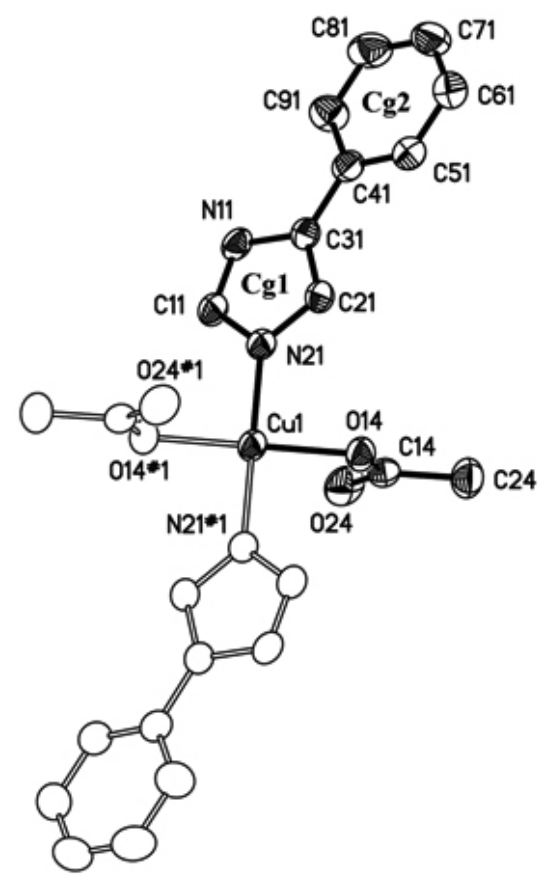

Fig. 3. Molecular view of the monomeric units in (3), showing the labelling scheme. Displacement ellipsoids drawn at a $30 \%$ level. Symmetry codes \#1, 1-x, 1-y, 1-z.

\section{b) Cobalt complexes:}

Compound (4) presents a single cobalt cation in a symmetry centre of a P-1 unit cell, octahedrally surrounded by six (only three of them independent) $\mathrm{N}$-coordinated 4-phim ligands (Fig. 4). The arrangement is almost ideal, with very small departures from regularity (Table 2). Charge balance occurs through a single (disordered) acetate ion located at a general position, balancing the cobalt(II) cation at a special position. We found the same regularity in the $\left[\mathrm{Co}(\mathrm{Im})_{6}\right]^{2+}$ belonging to the cobalt imidazole citrate complex $\left[\mathrm{Co}(\mathrm{Im})_{6}\right]\left[\mathrm{Co}_{\Delta}\right.$ $\left.\left.\left.(\mathrm{Im})_{3}\right) \mathrm{Hcit}\right)\right]\left[\mathrm{Co}_{\wedge}(\mathrm{Im})_{3}(\mathrm{Hcit})\right] \cdot 4 \mathrm{H}_{2} \mathrm{O}\left(\mathrm{Im}=\text { imidazole, } \mathrm{H}_{4} \text { cit }=\text { citric acid }\right)^{32}$

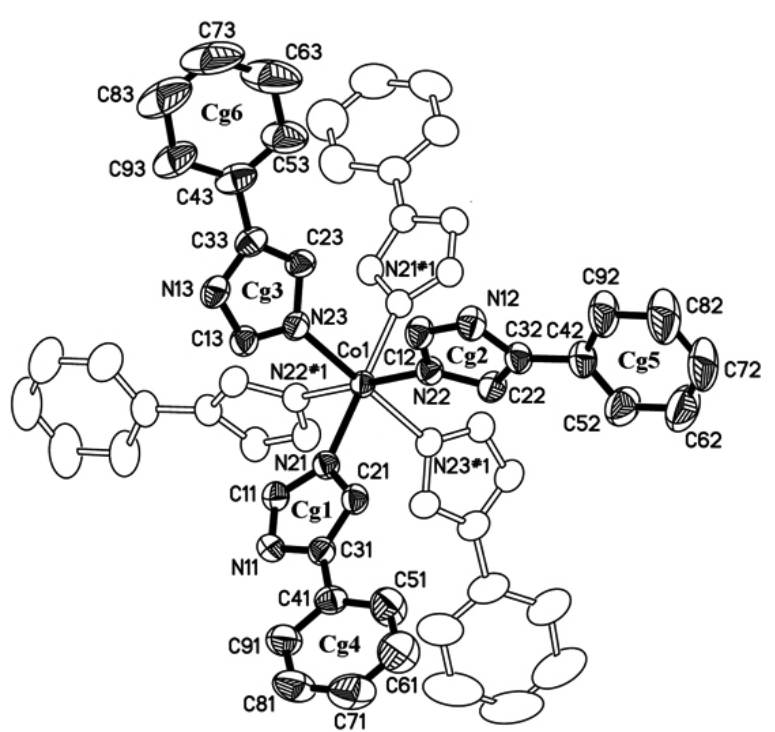

Fig. 4. Molecular view of the monomeric units in (4), showing the labelling scheme. Displacement ellipsoids drawn at a $30 \%$ level. Symmetry codes \#1, 1-x, 1-y, 1-z.

Compound (5) presents a tetrahedral geometry around the cobalt cation which lies in a general position, and it is defined by two independent 2-phim ligands and two monocoordinated acetato molecules (Fig. 5). It is interesting to compare the tetrahedral coordination geometry in (5) with the square planar one in (3), very different in spite of being composed of almost identical ligands binding cations of similar coordination characteristics. The reason should be searched in the different coordination sites of the 4-phim ligand of (3) and the 2-phim ligand of (5), of which the former allows the ligand to stretch away from the metal center to which it binds (Fig. 3), while the geometry of the latter precludes this behaviour, forcing it to remain near the cation. This might produce some sort of a steric hindrance inhibiting the approach and eventual binding of further ligands (Fig. 5). This coordination sphere is comparable with those corresponding to the $\left[\mathrm{Co}(\mathrm{pr})_{2}(\mathrm{Im})_{2}\right]$ complex $\left(\mathrm{pr}=\right.$ propionate $^{33}{ }^{33}$

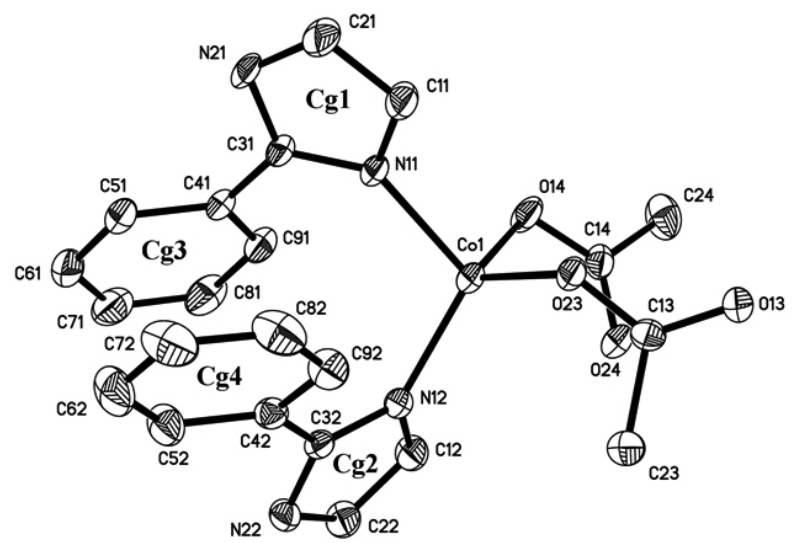

Fig. 5. Molecular view of the monomeric units in (5), showing the labelling scheme. Displacement ellipsoids drawn at a 30\% level.

All five structures present similar packing characteristics. Their stability is achieved by a diversity of $\mathrm{H}$-bonding interactions.

3.2 Biological studies

The in vitro antibacterial activity of complexes (1) to (5) was evaluated against representative Gram positive and Gram negative bacteria. The results of antibacterial activity and minimum inhibitory concentration (MIC) are reported in Tables 3 and 4 , respectively.

Table 3 shows the antimicrobial effect of the compounds using the paper 
disc diffusion method. Complex (2) did not show any antibacterial effect on the tested bacteria, while complexes (1), (3), (4), and (5) display activity over Gram negative and Gram positive bacteria.

Table 3. Qualitative antibacterial activity of copper and cobalt complexes with imidazole derivative ligands.

\begin{tabular}{|c|c|c|c|c|c|}
\hline \multirow{2}{*}{ Bacteria } & \multicolumn{5}{|c|}{ Complexes Inhibition Zone (mm)* } \\
\hline & (1) & (2) & (3) & (4) & (5) \\
\hline \multicolumn{6}{|l|}{ Gram negative } \\
\hline Escherichia coli DH5a & 9 & $\mathrm{R}$ & 11 & 16 & 17 \\
\hline Escherichia coli $\mathrm{O} 157: \mathrm{H} 7$ & 9 & $\mathrm{R}$ & 12 & 16 & 21 \\
\hline $\begin{array}{l}\text { Klebsiella pneumoniae } \\
\text { RYC492 }\end{array}$ & 8 & $\mathrm{R}$ & 13 & 14 & 17 \\
\hline Shigella flexneri UCH15 & $\mathrm{R}$ & $\mathrm{R}$ & 10 & 13 & $\mathrm{R}$ \\
\hline $\begin{array}{l}\text { Salmonella enteritidis } \\
\text { ISP/953 }\end{array}$ & 7 & $\mathrm{R}$ & 8 & 12 & ND \\
\hline $\begin{array}{l}\text { Salmonella enterica } \\
\text { UDP1313 }\end{array}$ & ND & $\mathrm{R}$ & 8 & 11 & ND \\
\hline Salmonella typhi ISP2714 & ND & $\mathrm{R}$ & 8 & 11 & 11 \\
\hline \multicolumn{6}{|l|}{ Gram positive } \\
\hline Staphylococcus aureus AB68 & 9 & $\mathrm{R}$ & 9 & 16 & 21 \\
\hline $\begin{array}{l}\text { Listeria monocytogenes } \\
\text { ATCC } 1513\end{array}$ & 7 & $\mathrm{R}$ & 9 & 15 & 22 \\
\hline
\end{tabular}

* Used disc with $600 \mu \mathrm{g}$ of complex. Number of assays $=3$, estimated error \pm 1 mm. (1): $\left[\mathrm{Cu}(5 \text {-nimd })_{2}\left(\mathrm{H}_{2} \mathrm{O}\right)_{2}\right]\left(\mathrm{NO}_{3}\right)_{2}$, (2): $\left[\mathrm{Cu}(4-\text { phim })_{4}\right]\left(\mathrm{NO}_{3}\right)_{2} \mathrm{CH}_{3} \mathrm{CH}_{2} \mathrm{OH}$, (3): $\left[\mathrm{Cu}(4-\text { phim })_{2}(\text { Acetate })_{2}\right]$, (4): [Co(4-phim $)_{6}$ (Acetate) $\left.)_{2}\right]$, (5): $\quad[\mathrm{Co}(2-$ phim $)_{2}(\text { Acetate })_{2}$ ], 5-nimd: 5-nitroimidazole, phim: phenylimidazole. ND: non determinate, $\mathrm{R}$ : resistant.

The complexes had MIC values around $3 \mathrm{mM}$ (Table 4), except complex (5) which showed MIC values ranging from 1-2 mM.

Table 4. Minimum inhibitory concentration (MIC) values of the copper complexes (1) and (3) and cobalt complexes (4) and (5).

\begin{tabular}{|l|l|l|l|l|}
\hline \multirow{2}{*}{\multicolumn{1}{|c|}{ Bacteria }} & \multicolumn{4}{c|}{ MIC (mM) } \\
\cline { 2 - 5 } & (1) & $\mathbf{( 3 )}$ & $\mathbf{( 4 )}$ & $\mathbf{( 5 )}$ \\
\hline Escherichia coli DH5a & 3.27 & 3.63 & 2.38 & 1.51 \\
\hline Escherichia coli O157:H7 & ND & 2.99 & 2.59 & 2.59 \\
\hline Klebsiella pneumoniae RYC492 & ND & 3.42 & 3.24 & 2.59 \\
\hline Shigella flexneri UCH15 & ND & 2.78 & 3.02 & ND \\
\hline Salmonella enteritidis ISP/953 & ND & 2.57 & 2.81 & ND \\
\hline Salmonella enterica UDP1313 & ND & ND & 2.16 & ND \\
\hline Salmonella typhi ISP2714 & ND & ND & 2.38 & ND \\
\hline Staphylococcus aureus AB68 & ND & 3.42 & 2.16 & 1.30 \\
\hline Listeria monocytogenes ATCC1513 & 2.45 & 2.99 & 2.16 & 1.16 \\
\hline
\end{tabular}

Number of assays $=3,(1):\left[\mathrm{Cu}(5 \text {-nimd })_{2}\left(\mathrm{H}_{2} \mathrm{O}\right)_{2}\right]\left(\mathrm{NO}_{3}\right)_{2}, \quad$ (3): $[\mathrm{Cu}(4-$ phim) $)_{2}$ (Acetate) $\left.)_{2}\right],(4):\left[\mathrm{Co}(4-\text { phim })_{6}(\text { Acetate })_{2}\right],(5):\left[\mathrm{Co}(2 \text {-phim })_{2}\right.$ (Acetate) $\left.{ }_{2}\right]$, 5-nimd: 5-nitroimidazole, phim: phenylimidazole. ND: non determinated, $\mathrm{R}$ : resisten

We used a plate assay to distinguish a bacteriolytic from a bacteriostatic mode of action of antimicrobial complexes. ${ }^{28}$ This method was based on the use of $\beta$-galactosidase as an appropriate marker of cellular lysis. If lysis occurs, the enzyme activity is released outside the bacterium and detected on the plate. When the enzyme reaches the agar medium, it hydrolyzes 5-bromo-4-chloro3 -indolyl- $\beta$-D-galactoside (X-Gal), a chromogenic compound included in the agar. After overnight incubation, $\mathrm{X}-\mathrm{Gal}$ forms a blue circle staining the edge of the inhibition zone produced by the antibiotic application. Only compounds causing cellular lysis produce a blue-colored edge at the inhibition zone.

The assay showed that complex (3) presents bacteriostatic activity because it does not produce a blue circle staining the edge of the inhibition zone, while complexes (4) and (5) present a bacteriolytic effect (Fig. 6). Tetracycline and ampicillin were used as control bacteriostatic and bacteriolytic agents,

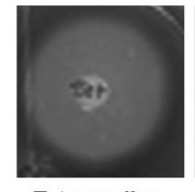

Tetracycline

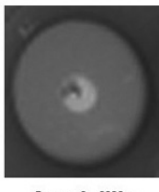

Ampicillin

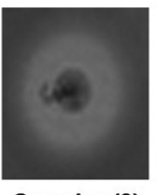

Complex (3)

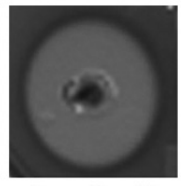

Complex (4)

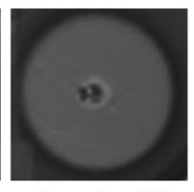

Complex (5) respectively.

Fig.6. Plate assay showing bacteriostatic or bacteriolytic effect for complexes (3), (4) and (5) over Gram negative bacteria Escherichia coli BL21(DE3). Used in assay disc with $600 \mathrm{mg}$ of analyzed complex. Disc of tetracycline $(300 \mu \mathrm{g})$ and ampicillin $(200 \mathrm{mg})$ were used as bacteriostatic and bacteriolytic control respectively.

The tests of bacterial growth kinetics agree with previous results, since complexes (1) and (3) display profiles of bacteriostatic agents (Fig. 7 and Fig. 8) over Listeria monocytogenes. On the other hand, the profiles of complexes (4) and (5) agree with a bacteriolytic effect (Fig. 9 and Fig. 10). These results support the plate assay data (Fig. 6) and confirm that the effects are valid for Gram positive and Gram negative bacteria.

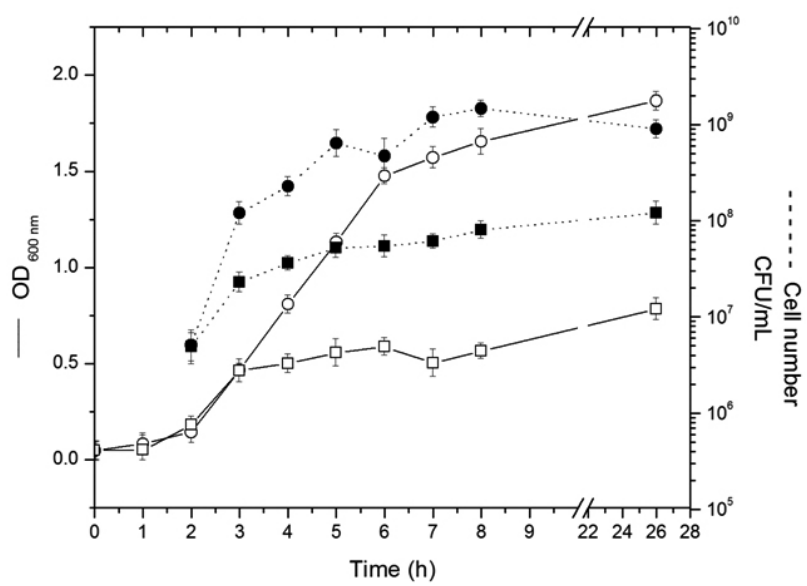

Fig.7. Effect of complex (1) on growth kinetic of Gram positive Listeria monocytogenes ATCC1513 bacteria. The complex (1) was used in concentration $2.45 \mathrm{mM}$

The different antibacterial effects of the complexes are associated mainly with the metal present in the coordination center. The complexes with cobalt metal centers present a bacteriolytic effect, while the complexes with copper metal centers display bacteriostatic activity.

In the case of copper complexes, the antibacterial activity is probably due to the nature of the core since the three compounds have the same geometry, square planar. The core in the complexes (1) and (3) is $\mathrm{CuN}_{2} \mathrm{O}_{2}$ and they have antibacterial activity whereas in the complex (2) the core is $\mathrm{CuN}_{4}$ not present activity. 


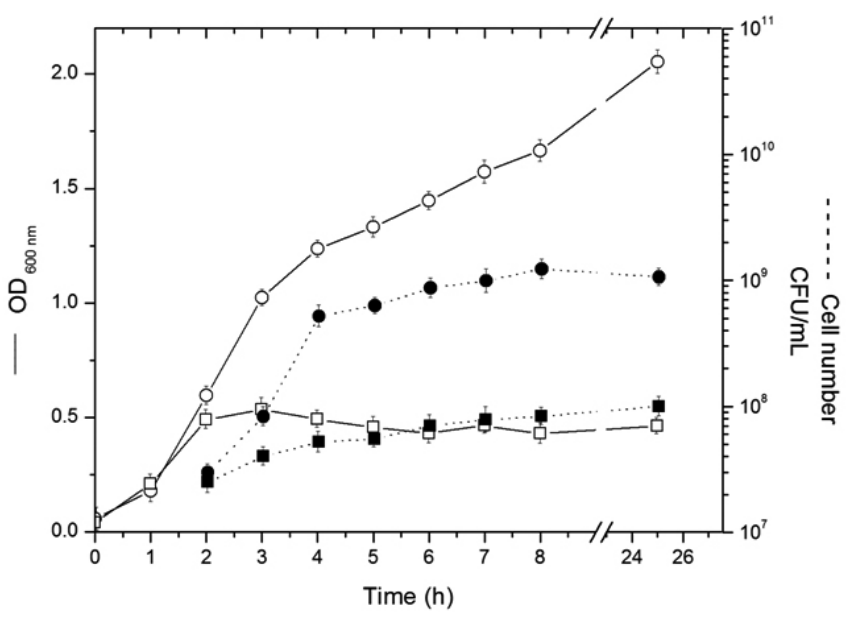

Fig.8. Effect of complex (3) on growth kinetic of Gram positive Listeria monocytogenes ATCC1513 bacteria. The complex (3) was used in concentration $2.84 \mathrm{mM}$.

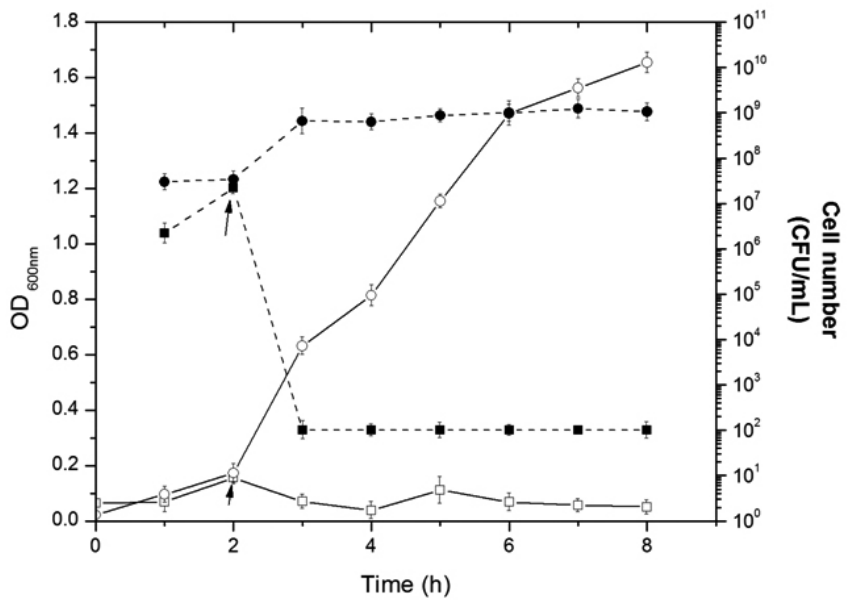

Fig.9. Effect of complex (4) on growth kinetic of Gram positive Listeria monocytogenes ATCC1513 bacteria. The complex (4) was used in concentration $2.16 \mathrm{mM}$

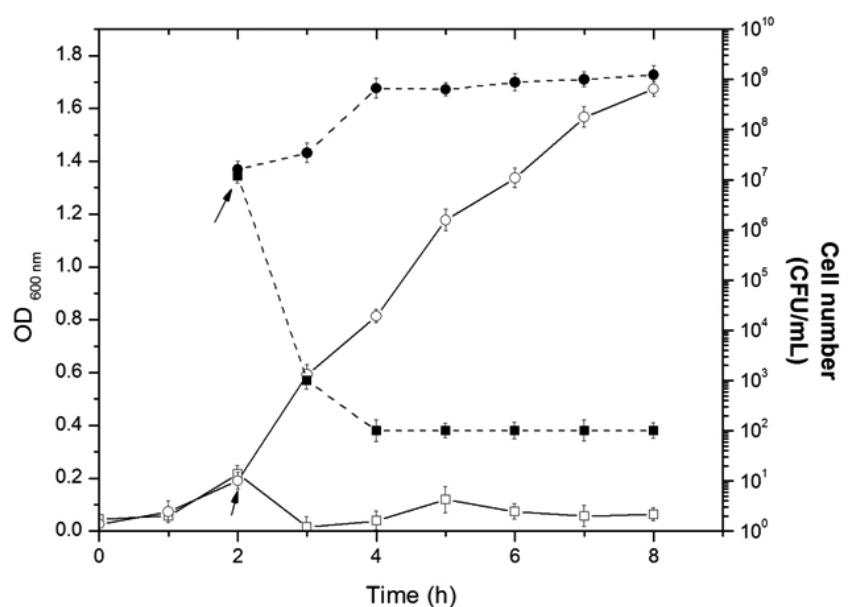

Fig 10. Effect of complex (5) on growth kinetic of Gram positive Listeria monocytogenes ATCC1513 bacteria. The complex (5) was used in concentration $1.16 \mathrm{mM}$
The toxicity of complexes (3) and (4) was tested on human kidney cells (Fig. 11). Their $\mathrm{IC}_{50}$ values were found to be $0.22 \mathrm{mM}$ and $0.67 \mathrm{mM}$, respectively. From the $\mathrm{IC}_{50}$ values, it is seen that the complexes show significant cytotoxic effect at concentrations close to the MIC.
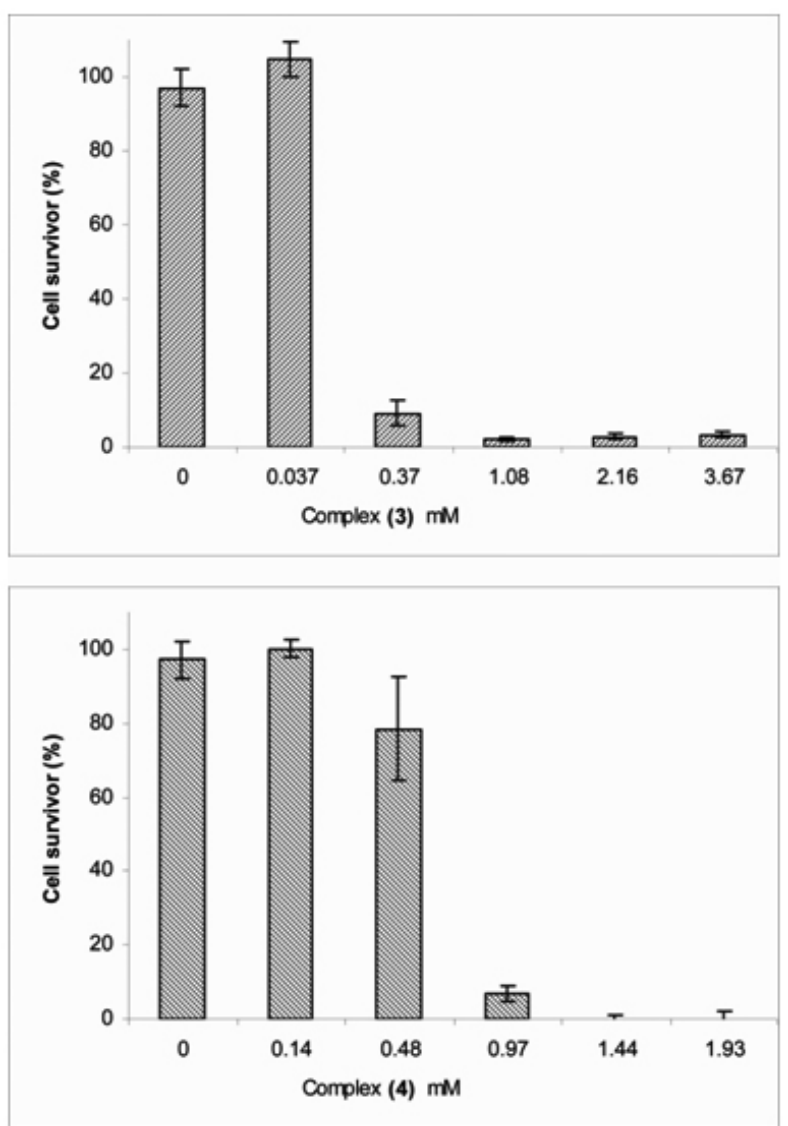

Fig 11. Cytotoxicity activity of complex (3) and (4) over human cells (HEK 293 cells).

Although these complexes have antibacterial activity, they are cytotoxic and are not appropriate for use as antibiotics or antiseptics. But under standard environmental control it would be possible to used complexes as disinfectants, because after being applied to a surface and later washed with water the toxicity would be very low, since remaining quantities would be 10 to 100 times smaller than the MIC, and cell survival at those concentrations is $100 \%$ (Fig. 11).

\section{Supplementary material}

Crystallographic data for the structural analysis have been deposited with the Cambridge Crystallographic Data Centre, CCDC No. 676236-676240. Copies of this information can be obtained free of charge from the Director, CCDC 12 Union Road, Cambridge, CB 21 EZ, UK (fax: +44-1223-336033); e-mail: deposit@ccdc-cam.ac.uk or http://www.ccdc.cam.ac.uk).

\section{ACKNOWLEDGEMENTS}

This research was supported by FONDECYT under project 1071061, and VRA Universidad Diego Portales.

\section{BIBLIOGRAPHY}

1. C. Orvig, M. J. Abrams, Chem. Rev., 99, 2201. (1999)

2. C. D. Garner, J. Chem. Soc. Dalton Trans., 3903. (1997)

3. B. D. Davis, H. N. Dulberco, H. S. Eiser, W. B. Ginsberg, Microbiology, 4th Ed. Harper and Row Publishers: Singapore, 1990. 
4. B. G. Malmstrom, L. E. Andreasson, B. Reinhammar, Copper-containing oxidases and superoxide dismutase. In The Enzymes vol. 12B; Boyer P. D. (ed.) Academic Press: New York, 1975, pp, 507-579.

5. P. Hemmerich, In The Biochemistry of Copper; J. Peisach, P. Aisen, W. E. Blumberg, (eds), Academic Press: New York and London, 1966.

6. S. J. Lippard, M. J. Berg, Principles of Bioinorganic Chemistry, University Science Books: Mill Valley, CA, 1994.

7. E. S. Sherman, J. S.; Lippard, Chem. Rev., 87, 1153 (1987).

8. P. Köpf-Maier, H. Köpf, Chem Rev., 87, 1137 (1987)

9. A. Hartwig, Pure Appl. Chem., 72, 1007 (2000)

10. S. Bellú, E. Hure, M. Frappé, C. Trossero, G. Molina, C. Drogo, P. Williams, A. M. Atria, J. C. Muñoz, M. Zacchino, M. Sortino, D. Campanogli, M. Rizzotto, Polyhedron, 24, 501 (2005).

11. N Raman, J. Joseph, A. Sakthivel, R.Jeymurugan J. Chil. Chem. Soc., 54, 354 (2009).

12. N Raman, S.Johnson Raja, J. Joseph, A. Sakthivel, J.Dhaveethu Raja, J. Chil. Chem. Soc., 53, 1599 (2008)

13. E. Greenaway, J. J. Riviere, X. Girerd, G. Labouze, B. Morgant, J. C. Viossat, M. Daran, N. H. Roch, N. H.; Dung. J. Inorg. Biochem., 76, 19 (1999).

14. P. Cortés, A. M. Atria, M. Contreras, M. T. Garland, O. Peña, G. Corsini, J. Chil. Chem. Soc., 51, 957 (2006).

15. B. Viossat, J. C. Daran, G. Savouret, G. Morgant, F. T. Greenaway, N. H. Dung, V. A. Pham-Tram, R. J. Sorenson, J. Inorg. Biochem., 96, 375 (2003).

16. K. Z. Ismail, A. El-Dissouky, A. Z Shehada, Polyhedron, 16, 2909 (1997).

17. M. Navarro, E. J. Cisneros-Fajardo, T. Lehmann, R. A. Sanchez-Delgado, R. Atencio, P. Silva, R. Lira, J. A. Urbina, Inorg. Chem., 40, 6879 (2001).
18. P. R. Bontchev, I. N. Pantcheva, T. Todorov, D. R. Mehandjiev, N. S. Savov, J. Inorg. Biochem., 83, 25 (2001).

19. H. Tamura, H.; Imai, J. Kuwahara, Y. Sugiura, J. Am. Chem. Soc., 109, 6870 (1987)

20. A. Klanicová, Z. Trávníček, I. Popa, M. Čajan, K. Doležal, Polyhedron, 25, 1421 (2006).

21. Bruker SMART_NT. Version 5.624 Bruker AXS Inc. Madison Wisconsin USA., 2001

22. Bruker SAINT NT. Version 6.02a. Bruker AXS INC. Madison, Wisconsin USA., 2000.

23. G. M. Sheldrick, SHELXS97 and SHELXL97; Programs for Structure Resolution and for Structure Refinement; University Göttingen, Germany, 1997.

24. G. M. Sheldrick, SHELXTL/PC. Version 5.03. Siemens Analytical X-ray Instruments Inc., Madison, Wisconsin, USA., 1994.

25. F. H. Allen, Acta Cryst., B58, 380 (2002).

26. K. L. Kwaniewska, Bull. Environ. Contam. Toxicol., 27, 289 (1981).

27. National Committee for Clinical Laboratory Standards; Methods for Dilution Antimicrobial Susceptibility Tests for Bacteria That Grow Aerobically, Fifth Edition: Approved Standard M7-A5. NCCLS, Wayne, PA, USA, 2000.

28. G. Mardones, A. Venegas, J. Microbiol. Meth., 40, 199 (2000)

29. A. A. Van de Loosdrecht, R. H. Beelen, G. J. Ossenkoppele, M. G. Broekhoven, M. M. Langenhuijsen, J. Immunol. Methods, 174, 311 (1994).

30. A. L. Abuhijleh, C. Woods, Inorg. Chim. Acta, 194, 9 (1992).

31. Y. Wang, Q. Shi, Q.; Shi, Y. Gao, Z. Zhou, Polyhedron, 18, 2009 (1999).

32. Y. Deng, Z. Zhou, Z. Cao, K. Tsai, J. Inorg. Biochem., 98, 1110 (2004).

33. W. D. Horrocks, J. N. Ishley, R. Whittle, Inorg. Chem., 21, 3265 (1982). 